\title{
Perspektiewe op die stand van die Ou-Testamentiese wetenskap in Groot Brittanje
}

W S Prinsloo

\begin{abstract}
Perspectives on the position of the study of the Old Testament in Great Britain

This article is the result of conversations with a number of leading Old Testament scholars in Great Britain. It attempts to identify important trends in the Old Testament discipline in Great Britain, and to indicate its relevance for the study of the Old Testament in South Africa
\end{abstract}

1 Inleidend

Hoewel ons in Suid-Afrika oor die jare heen kontak met Groot Brittanje gehad het en selfs uit die oord beïnvloed is, is die Ou-Testamentiese wetenskap hier ter lande hoofsaaklik vanuit Holland en Duitsland gevoed. In die afgelope aantal jare het die invloed van die VSA ook toenemend belangriker geword. Dit sou dus sinvol wees om ook navraag te doen na die huidige stand van die Ou-Testamentiese wetenskap in Groot Brittanje. Tydens die Europese somer van 1991 het ek hesoeke aan verskeie universiteite in Engeland en Skotland gebring juis met dié doel voor oë.

Wat hier volg is die resultaat van gesprekke wat met ' $n$ aantal van die mees toonaangewende $\mathrm{Ou}$-Testamentici aldaar gevoer is. Hoewel die meeste van die geleerdes goed aan ons bekend is uit hulle publikasies was dit tog sinvol om pertinente vrae aan hulle te vra en om onmiddellike reaksie op sekere stellings te verkry. Dit is natuurlik onmoontlik om op grond van enkele gesprekke tot 'n konklusie oor die algemene stand van sake te kom. Tog is dit moontlik om sekere tendense en ontwikkelinge aan te wys wanneer daar met 'n groep verteenwoordigend van 'n verskeidenheid van eksegetiese en konfessionele invalshoeke gesprekke gevoer word.

Die gesprekke het gesentreer om die verhouding tussen wat ek as die drie basiese elemente van die kommunikasieproses van tekste beskou, naamlik die outeur (en alle vrae rondom die historiese situasie en die ontstaansproses van die teks), die teks en die leser. Wie op hoogte is met die navorsingsgeskiedenis van die eksegese van die Ou Testament sal weet dat die metodologiese debat die afgelope aantal jare juis gekonsentreer het op die vraag na die verhouding tussen hierdie drie sake.

Hoewel gepoog is om die gespekke met die onderskeie Ou-Testamentici so getrou en "objektief" as moontlik weer te gee, word die eksegete ook maar deur die bril van die gespreksvoerder "gelees" sodat daar tog nie volkome aan subjektiwiteit ontkom kan word nie. Gesprekke is met die volgende Ou-Testamentici gevoer: 

Brittanje

2.1 Prof William McKane (St Mary's College, University of St Andrews) is veral bckend vanweë sy monumentale kommentaar op Spreuke ${ }^{1}$ en sy kommentaar op die eerste gedeelte van Jeremia ${ }^{2}$. Hy werk op die oomblik aan die voltooiing van die tweede deel van sy Jeremiakommentaar en 'n huldigingsbundel is ook 'n paar jaar gelede aan hom opgedra ${ }^{3}$. Hy ag die tekskritiek en die resepsiegeskiedenis van die Hebreeuse Bybel in die Christelike kerk van groot belang en het ook al daaroor gepublisee ${ }^{4}$. Hy het 'n diakroniese benadering tot die teks. Hoewel hy die rekonstruksie van die groei van die teks as van groot belang ag, beskou hy die werksmetode van die literêre kritiek tog as baie spekulatief. Hy vind ook nie veel aanklank by die kanoniese benadering nie, omdat die finale teks volgens hom slegs die einde van die proses van herinterpretasie is en dus nie noodwendig belangriker as die voorafgaande fases is nie.

In sy eksegetiese arbeid is dit vir hom belangrik om byvoorbeeld die situasie van die profeet Jeremia en dié se oorspronklike woorde te rekonstrueer. Hy probeer om deur die analise van die teks agter te kom wat die bedoeling van die outeur was. Om te weet wat die profeet Jeremia sou gesê het, is dus belangrik vir McKane. Anders as wat Holladay ${ }^{5}$ gedoen het in sy kommentaar probeer McKane egter nie om alles in die boek Jeremia aan die profeet Jeremia toe te skryf nie. Waar McKane in van sy vroeëre geskrifte ${ }^{6}$ ' $n$ soort van digotomie of konflik tussen die profete en die wysheid gesien het, is hy nou nie meer so seker van sy saak wat dié aspek betref nie.

Hy plaas 'n geweldige hoë premie op die bestudering van Hebreeus as voorvereiste vir die beoefening van die Ou-Testamentiese eksegese. Hy word nie werklik beïndruk deur die lesersgeoriënteerde benadering nie. Volgens McKane kan jy nie werklik met die beoefenaars van dié metode in debat tree nie omdat elkeen basies doen wat hy wil en dit is ook reg in die oë van die betrokke eksegeet. Tog erken McKane dat daar 'n "marriage" tussen die leser en die teks plaasvind. Een van die punte van kritiek teen die "reader oriented"-eksegete is egter juis dat hulle nie genoeg aandag aan die Hebreeus gee nie.

Wat die beoefening van die Ou Testament teologie betref sou hy eerder by 'n benadering soos dié van von Rad as by Eichrodt wou aansluit. Hy erken dat hy baie deur Wellhausen beïnvloed is. Wat huidige Ou-Testamentici betref het hy 'n hoë agting vir Rudolph Smend, veral omdat $h$ 'n sterk historiese bewussyn het.

2.2 Prof William Johnstone (Department of Hebrew and Semitic Languages, King's College, University of Aberdeen) spesialiseer veral op Kronieke en Eksodus?. Hy het 'n sinkroniese aanpak, dus begin hy met die finale, kanoniese teks soos wat dit nou daar uitsien ${ }^{8}$. Hy sê dat eksegese soos argeologie is, 'n mens moet altyd met die "upper level" begin en dan afwerk na onder toe. Hoewel hy die diakroniese werk as komplementêr tot die sinkroniese sien, lyk dit nie of hy veel belangstel in die "onderste lae" nie, en dat hy hoofsaaklik in die finale teks belangstel. Hy glo dat die "canonizing community" 'n spesifieke doel met die finale teks gehad het.

Vanweë sy kanoniese benadering glo hy dat daar doelbewuste "coherence" in die hele Ou Testament is en dat 'n mens dus wel van 'n teologie van die Ou 
Testament kan praat. Juis omdat Kronieke die laaste ( $\mathrm{d}$ kanonies die laaste) boek in die Ou Testament is, konsentreer hy op dié boek omdat hy glo dat die laaste boek die sleutel verskaf tot die verstaan van die Ou Testament. Eksegese is, volgens Johnstone, 'n deskriptiewe wetenskap om die doelbewuste betekenis of "intention" van die teks te beskryf. Daar is dus sekere objektiewe sake in die teks. In dié sin het hy gevolglik kritiek teen die lesersgeoriënteerde benadering en die dekonstruktiewe lees van tekste, want sé Johnstone, daar is doelbewuste, objektiewe gegewenhede in die teks waaraan die leser hom moet steur. Om dié rede kan hy dit nie aanvaar dat die leser die "boss" is nie (vgl die opmerkings by D J A Clines). Die kriterium waarvolgens gewerk moet word is dit wat in die teks staan. Hy glo dat hy self objektief na die teks toe gaan. In sy werk op Kronieke, se hy, het hy die teks intensief, sonder "Vorverständnis" bestudeer. Op die manier, glo hy, kom hy by die ware betekenis van die teks uit. Op 'n vraag of die "balance structures", wat hy geneig is om in tekste te bespeur', nie dalk eerder in die kop van die eksegeet as in die teks is nie, is sy antwoord dat hy oortuig is dat dit wel in die teks is omdat hy objektief na die teks toe gaan.

$\mathrm{Hy}$ is nie veel in die geskiedenis of historiese aspekte geïnteresseerd nie, maar eerder in die teologiese "intention or construction" van die teks. Ter illustrasie kan genoem word dat hy ten opsigte van die Eksodusverhaal meer in die "theological statement" as in die "actual historical process" belangstel ${ }^{10}$. Hieruit volg logies dat hy nie eintlik aanklank vind by en simpatie het met die histories-kritiese benadering nie.

23 Dr Terence Collins (Theological Faculty, University of Manchester) is veral bekend vanweë sy proefskrif oor die Hebreeuse poësie ${ }^{11}$. In sy boek word die belangrike stelling gemaak dat daar in die verlede twee basiese benaderings tot Hebreeuse poësie was: Aan die eenkant het die mening geheers dat die metrum die belangrikste kenmerk van die Hebreeuse poësie was; aan die anderkant word gese dat parallelisme die uitstaande kenmerk van Hebreeuse poësie is. Collins kom met 'n nuwe gedagte, naamlik dat die sintaksis van Hebreeuse versreëls van deurslaggewende belang moet wees by die analise daarvan. Hy verfyn dan ook sy metode deur vier basiese sinstipes by die Hebreeuse poësie te identifiseer. Kritiek wat soms teen Collins ingebring word is dat sy benadering ook maar eensydig is ${ }^{12}$, aangesien sintaksis slegs één van die boustene van die Hebreeuse poësie is. Is sy benadering komprehensief genoeg? Is hy nie eklekties in sy keuse van tekste nie? Hy het ook slegs tekste uit die profetiese literatuur geneem as voorbeelde. In reaksie op hierdie stellings sê Collins dat daar onthou moet word dat sy boek 'n proefskrif was en dat hy slegs 'n klein seleksie uit die Ou-Testamentiese literatuur kon maak. Sy proefskrif was dus nie bedoel om omvattend te wees nie. Hy het byvoorbeeld net na verbale sinne gekyk en nie ook na nominale sinne nie. Toe hy sy proefskrif geskryf het was dit sy mening dat die "syntactical patterns" afgeskeep word by die bestudering van Hebreeuse poësie, daarom wou hy dié aspek sterk beklemtoon. Hy pleit dus ook vir 'n omvattende of komprehensiewe benadering waarin al die elemente van die Hebreeuse poësie tot hulle reg kom. Hy praat van fonologiese, semantiese en stilistiese aspekte. In die jongste verlede het hy 'n artikel geskryf ${ }^{13}$ waarin hy sy benadering tot die analise van die psalms duidelik uiteensit.

Wat die verhouding tussen die sinkroniese en diakroniese fasette van die eksegetiese proses betref, is hy van mening dat dit twee maniere is om na 'n teks te 
kyk. Die twee fasette moet egter volgens hom afsonderlik op 'n teks toegepas word en nie gelyktydig nie. Nadat albei aspekte bestudeer is, kan daar 'n sintese gemaak word. Vir Collins is dit nie belangrik dat die sinkroniese werk voor die diakroniese moet geskied nie. Dit kan ook andersom geskied. Dit hang van die navorser af en wat hy met sy eksegese wil bereik. Collins erken dat ons elkeen met ons "preconditions" na 'n teks toe kom. Die leser het gevolglik 'n uiters belangrike rol en om te lees is ' $n$ kreatiewe proses. Die leser het egter nie vrye teuels nie, want hy word deur die teks gebind en beïnvloed. Daar moet dus 'n dialoog tussen die teks en die leser plaasvind.

Collins het pas 'n boek vir publikasie aangebied waarin hy die hipotese huldig dat die sogenaamde Twaalf Klein Profete oorspronklik een boek was omdat dié geskrifte as geheel dieselfde eienskappe vertoon as die sogenaamde Groot Profete.

Die Ou Testament teologie is vir Collins dié deel van die Ou-Testamentiese wetenskap wat sistematiseer wat die Ou Testament oor God sê. Daar is egter nie 'n teologie in die Ou Testament self nie. Ou Testament teologie is ons sistematisering en interpretasie van die Ou Testament vir vandag.

2.4 Dr John Goldingay, die hoof van St John's College, Nottingham, 'n teologiese seminarium van die "Church of England", het die afgelope aantal jare wyd gepubliseer. Van sy bekendste werke is 'n resente, omvattende kommentaar op Daniël14 en werke oor die teologie en interpretasiegeskiedenis van die $\mathrm{Ou}$ Testament ${ }^{15}$. Goldingay is van mening dat die teks moet bepaal watter eksegetiese metode gevolg behoort te word: As 'n profeteboek 'n historiese opskrif het, dan kan ' $n$ mens nie anders as om historiese vrae te vra nie. Genesis 1 leen hom byvoorbeeld volgens Goldingay meer tot ' $n$ histories-kritiese lees, terwyl Genesis 2-3 'n meer sinkroniese benadering vereis.

Hy gee in sy publikasies baie aandag aan wat hy noem die verhouding tussen "history" en "story"16. In die Ou Testament het ons meestal "stories", maar dit is gebou op dinge wat werklik gebeur het - op "history". By 'n boek soos Kronieke is die "history" deel oorwegend, terwyl by Jona die "story" deel weer oorwegend is. Die gesag van die $\mathrm{Ou}$ Testament is vir hom baie belangrik. Die diversiteit van die $\mathrm{Ou}$ Testament bring ook nie die gesag van die Ou Testament in gedrang nie. Aangesien die geloofsgemeenskap die Ou Testament as geheel oorgelewer het, moet daar 'n samebindende faktor te midde van die diversiteit wees. Hy beskryf dié samebindende faktor as God en sy verhouding tot mens en wêreld.

Hy verwerp 'n oordrewe "reader-oriented" aanslag op die teks en sê dat ons eerder teksgeoriënteerd moet wees. Daar is sekere objektiewe waarhede in die teks wat bedoel is om deur die leser ontdek te word en wat bedoel is om as riglyne vir ons lewe te dien. Tog kan 'n mens, volgens Goldingay, nie ontken dat die leser met 'n klomp voorkennis na die teks toe kom nie en dat daar "missing gaps" is wat ingevul moet word nie. Hy gebruik die volgende beeld om die interpretasieproses te beskryf: Dit is soos 'n inkleurprent waarvan ons slegs die buitelyne het, maar wat ons self moet inkleur - dit wil sê interpreteer - om sodoende ook vir ons 'n boodskap daaruit te kry. Vanweë die feit dat hy aan 'n kerklike opleidingsentrum verbonde is, is dit vir hom baie belangrik om by die boodskap en die prediking van die teks uit te kom. 
2.5 Prof John Rogerson (Department of Biblical Studies, University of Sheffield) is veral bekend vanweë sy kommentaar op die psalms ${ }^{17}$. Die benadering wat in dié psalmkommentaar gevolg is, word soos volg deur Rogerson verwoord 18: "In the present commentary, the writers have tried to strike a balance between the spiritual, historical, form-critical and cultic approaches, seeing value in each where appropriate. The writers have also tried to bring out the religious teaching which they believe the psalms to contain". Rogerson sê dat hy vandag nog steeds min of meer dieselfde benadering het. Hy dink dat dit egter baie hipoteties is om die kultiese situasie (a la Mowinckel) van elke psalm te rekonstrueer. Hy het dit ook daarteen om die psalms (a la Gunkel) op geforseerde wyse by 'n Gattung in te dwing. Hy het groot waardering vir en het ook 'n lewendige kontak met Wolfgang Richter ${ }^{19}$ en lede van die Richterskool. Hy is dan ook van mening dat Richter met reg kritiek teen die histories-kritiese metode uitgespreek het. Hy het ook'n artikel geskryf in 'n huldigingsbundel van Richter wat nog in voorbereiding vir publikasie is 20 . Interessant genoeg het Rogerson nog nie veel kennis geneem van sy eie landgenoot, W G E Watson ${ }^{21}$, wat uiters belangrike werk op die die vakterrein van die Hebreeuse poësie gedoen het nie.

Rogerson spreek kritiek teen die lesersgeoriënteerde benadering, of soos hy verkies om dit te noem, die dekonstruktiewe lees van die Ou Testament uit want, sé hy, die teks self het iets om te sé. Tog beoefen hy $(m i)$ in 'n sekere sin ook 'n lesersgeorienteerde benadering want, sê hy, daar is nie so iets as 'n deskriptiewe Ou Testament teologie nie. Hy beplan gevolglik om 'n Ou Testament teologie te skryf met Habermas se kommunikasiemodel as basis. Dus, 'n teologie wat iets vir vandag te sê het. Hy erken dat dit 'n subjektiewe aangeleentheid is.

Rogerson het ook 'n groot belangstelling in die Forschungsgeschichte 22 en die antroplogie ${ }^{23}$ van die Ou Testament.

2.6 Prof D J A Clines, soos Rogerson, verbonde aan die Department of Biblical Studies, University of Sheffield, is waarskynlik dié eksponent van die lesersgeoriënteerde benadering in Brittanje 24 . Clines sê onomwonde: "The reader is the boss". 'n Leser ken betekenis toe volgens die reëls van die gemeenskap waarin hy leef. Die leser laat hom dus nie bind deur die outeur of die teks nie. As die leser (of die gemeenskap) byvoorbeeld sou besluit om die psalms nie as poësie te vertaal nie, dan is dié psalms nie poësie nie. Clines meen dat selfs chiasmes of parallelismes iets is wat die leser aan die teks toeken en wat nie noodwendig in die teks staan nie. As jy vir iemand sou vra in watter taal die Bybel geskryf is en hy antwoord dat dit Engels is (en nie Hebreeus nie), dan is dit so. Op 'n vraag aan Clines of 'n mens dan überhaupt 'n teks nodig het, sè Clines dat elke leser 'n teks nodig het en dat elke teks'n outeur het!

2.7 Prof R E Clements (King's College, University of London) is veral bekend vanweë sy Ou Testament teologie 25 en sy publikasies op Deuteronomium en Jesaja ${ }^{26}$. Hoewel hy nie 'n starre, onbuigsame mening oor die verhouding sinkronie/diakronie het nie, begin hy tog met die teks "as it stands today". In effek beteken laasgenoemde vir hom Biblia Hebraica Stuttgartensia. Hy ag die diakroniese aspekte en die resultate van die histories-kritiese metode egter ook as van groot belang. By die bestudering van byvoorbeeld Deuteronomium is dit belangrik om kennis te neem van die bronnehipotese. 
Clements het nog nie veel nagedink oor die rol van die leser in die eksegetiese proses nie. Tog dink hy dat ons as moderne lesers met sekere "guiding theological principals" na die Skrif toe moet gaan. Hiermee bedoel hy eintlik dat die kerklike tradisie as riglyn moet dien vir die eksegese. Hy erken dat dié "guiding principles" miskien nie direk in die Skrif staan nie, maar reken tog dat dit latent daar teenwoordig is. As 'n mens sy teologie op die Ou Testament lees, tree dié benadering van hom duidelik na vore. Kritiek wat soms teen Clements se Ou Testament teologie ingebring word is juis dat dit te dogmaties ingeklee is.

Oor die verhouding Ou Testament/Nuwe Testament is sy opvatting dat ons as Christene nie anders kan as om die Nuwe Testament ernstig op te neem wanneer dit oor die Ou Testament praat nie. Nuwe-Testamentiese "aanhalings" van die Ou Testament moet as kriterium geld vir die interpretasie van die Ou Testament. Ons moet probeer om, soos hy sê, die Ou Testament deur die "oë van Christus" te lees. Dit lyk egter nie of Clements die problematiek verbonde aan die "aanhalings" van die Ou Testament deur die Nuwe Testament werklik al krities deurdink het nie.

Clements het baie simpatie met die kanoniese benadering van B S Childs. Hy sê dat as hy die Ou Testament teologie, wat hy in die laat sewentigerjare geskryf het, weer sou moes oorskryf hy dit egter heel anders sou doen. Hy sou meer beweeg in die rigting van 'n Bybelse teologie en sowel die Ou as die Nuwe Testament in berekening bring.

\section{Samevatting en algemene indrukke}

3.1 Dat die peil van navorsing op die terrein van die Ou-Testamentiese wetenskap op 'n hoë vlak in Gront Brittanje is, kan nie weg geredeneer word nie. Dit blyk veral uit die publikasies en die hoë standaard van navorsing. Dit lei geen twyfel nie dat ons in Suid-Afrika nog meer as in die verlede op verskeie maniere kontak moet soek en moet uitbou met kollegas aldaar. Dat hulle 'n wesenlike bydrae kan maak tot die verdere bevordering van die wetenskap in ons eie land lei geen twyfel nie.

3.2 Die Ou Testament word vanuit 'n verskeidenheid van invalshoeke en met behulp van verskillende metodes ondersoek. Hoewel dit so is dat die sinkroniese benadering waarskynlik oorheersend voorkom, kan 'n mens nie sê dat dit dié metode is wat in Brittanje aan die orde is nie. Soos wat dit ondere andere na.vore tree uit bogenoemde gesprekke blyk dit dat daar ook beoefenaars van die historieskritiese metode en diegene is wat 'n lesersgeorienteerde benadering voorstaan.

Dit is belangrik om daarop te wys dat elke eksegeet se metode grootliks bepaal word deur die "skool" waaraan hy verbonde is, deur sy konfessionele of kerklike verbintenis en deur die feit of hy predikante vir 'n spesifieke kerk oplei en of hy Ou Testament aan 'n "Faculty of Arts" doseer. Dit beklemtoon weer eens die relatiwiteit van ons eie eksegetiese metodes en behoort ons tot nederigheid te stem om nie van ons eie metode(s) dié metode te maak en te maak asof ons sonder vooronderstellings en objektief na die teks toe gaan nie.

Gesprekke en eerstehandse kontak met buitelandse vakgenote oor die metodologie van eksegese en oor ander vakwetenskaplike vraagstukke bly om ten minste twee redes belangrik: Eerstens is dit goed om kennis te neem van wat ander eksegete doen; tweedens dwing dit jou om in die lig van wat ander mense doen rekenskap van jou eie benadering te gee en krities na jou eie werksmetode te kyk. 
3.3 Vanweë die minder gunstige posisie van die ekonomie in Brittanje trek universiteite oor die algemeen, en teologiese fakulteite en departemente $\mathrm{Ou}$ Testament en "Biblical Studies" in besonder, maar noustrop. Die kleiner rol wat die kerk in die gemeenskap inneem, het ook tot gevolg dat daar minder studente vir teologiese opleiding aanmeld. Al die faktore werk daartoe mee dat sommige leerstoele wat vakant raak nie weer gevul word nie of ten minste nie weer op professorale vlak gevul word nie.

'n Kommerwekkende verskynsel is dat die bestudering van die grondtale (Hebreeus en Grieks) by sommige universiteite nie meer 'n verpligte voorvereiste vir die teologiese studie is nie. Dit laat die ernstige vraag ontstaan waar die volgende geslag Ou- en Nuwe-Testamentici vandaan gaan kom. Die sterk tradisie wat aan die Universiteit van Pretoria en aan ander Suid-Afrikaanse universiteite gevestig is, naamlik dat 'n grondige bestudering van Grieks en Hebreeus 'n noodsaaklike voorvereiste vir die bestudering van die teologie in die algemeen en van die Ou en Nuwe Testament in besonder is, moet ten alle koste behou en uitgebou word.

Nog ' $n$ kenmerk van die situasie in Brittanje is dat teologie (en dus die Ou Testament) by sommige universiteite as ' $n$ "sekulêre" wetenskap in ' $n$ "Faculty of Arts" aangebied word. So 'n departement is nie kerklik verbonde nie en voornemende predikante wat daar studeer moet gevolglik hulle studies afrond by die teologiese seminarium van die betrokke kerk waar hulle in die bediening wil tree. My voorlopige waarneming is dat 'n teologie wat nie kerklik-konfessioneel verbonde is nie gevaar loop om in ivoortoringteologie te verval. ' $n$ Kerklik-konfessionele teologie is nie noodwendig minder wetenskaplik as 'n "sekulêre" teologie nie. Geen teologie - om die waarheid te sê geen wetenskap nie - kan op objektiwiteit aanspraak maak nie.

\section{NOTAS}

1 W Mckane, Proverss (Old Testament Library), London 1970.

2 W McKane, A critical and exegetical commentary on Jeremia vol I (ICC), Edinburgh 1986.

3 J D Martin \& P R Davis (eds), A word in season. Essays in honour of William Mckane (JSOT SS 42), Sheffield 1986.

4 Sy jongste boek (cf W Mckane, Selected Christian Hebraists, Cambridge 1989) getuig hiervan.

5 Vergelyk W L Holladay, Jeremiah 1. A commentary on the book of the prophet Jeremiah, chapter 1-25 (Hermeneia), Philadelphia 1986; Jeremiah 2. A commentary on the book of the prophet Jeremiah, chapters 26-52 (Hermeneia), Philadelphia 1989.

W McKane, Prophets and wise men, London 1965.

Vergelyk byvoorbeeld W Johnstone, "The Exodus as process", The Expository 
Times 91 (1979/80), 358-363; "Guilt and atonement: The theme of I and II Chronicles", in: J D Martin \& P R Davies, $A$ word in season. Essays in honour of William McKane (JSOT SS 42), Sheffield 1986, 113-138; "Reactivating the Chronicles analogy in Pentateuch studies, with special reference to the Sinai pericope in Exodus", ZAW 99 (1987), 16-37.

8 Johnstone formuleer dit elders ( $a w, 1987,17)$ soos volg: "...it is the final, summated form of the material as it palpably stands in the Old Testament at present, which provides the interpreter with some kind of solid ground...It is furthermore helpful to start study with the canonical form of the text, for that is the common ground on which interpreters of all view-points can meet".

$9 \quad$ Vergelyk byvoorbeeld Johnstone, $a w, 1986,128,132,135$.

10 Vergelyk Johnstone, $a w, 1979-80,358 \mathrm{ev}$.

11 T Collins, Line-forms in Hebrew poetry. A grammatical approach to the stylistic study of the Hebrew prophets (Studia Pohl: Series maior 7), Rome 1978.

12 Kyk G T M Prinsloo, 'n Literêr-eksegetiese analise van die boek Habakuk, Pretoria 1989 (ongepubliseerde DD-proefskrif, Universiteit van Pretoria), 54.

13 Kyk T Collins, "Decoding the psalms: A structural approach to the psalter", JSOT 37 (1987), 41-55, waarin hy 'n "structural approach" tot die psalms bepleit. Hy sien sy benadering as komplementêr tot en selfs as 'n natuurlike verlenging van die vormkritiek. Sy benadering omvat veral drie belangrike fasette: Eerstens, die bepaling van wat hy die konstante semantiese komponente of die "modes of discourse" van die psalms noem. Tweedens, moet die verhouding tussen bogenoemde elemente bepaal word. Hy is van mening dat die patroon van "binary oppositions" oorheersend is. Derdens beklemtoon hy ook, wat hy noem, die implisiete narratiewe aard van die psalms. Hy gebruik dan ook die aktante model van Greimas in dié verband.

14 J E Goldingay, Daniel (WBC 30), Dallas, Texas 1989.

15 Kyk J E Goldingay, "The study of Old Testament Theology. Its aims and purpose", Tyndale Bulletin 26 (1975), 34-52; "Diversity and unity in Old Testament Theology", VT 34/2 (1984), 153-168; Theological diversity and the authority of the Old Testament, Grand Rapids 1987; Approaches to Old Testament interpretation, Leicester 21990 . Vir 'n bespreking van die belangrike rol wat Goldingay in die debat rondom die Ou Testament teologie speel, kyk G F Hasel, "Old Testament Theology from 1978-1987", Andrews University Seminary Studies 26/2 (1988), 142-146.

16 Vergelyk Goldingay, $a w, 1989$

17 J W Rogerson \& J W Mckay, Psalms 101-150 (The Cambridge Bible Commentary), Cambridge 1977.

Rogerson, $a w, 8$. 
19 Vir die benadering van Richter, vergelyk W Richter, Exegese als Literaturwissenschaft. Entwurf einer altestamentliche Literaturtheorie und Methodologie, Göttingen 1971.

20 In dié artikel ("Exegese als Literaturwissenschaft: revisited") spreek hy homself soos volg oor die Richterbenadering uit: "The Richter method should not, therefore, be seen simply as a purist or formalist exercise in literary criticism that has been outflanked by recent developments in feminist and deconstructionist critisism. It has, in my view, much wider ramifications in providing the essential foundation for a new theory of biblical interpretation grounded in the rational infrastructure of communication, and worked out in dialogue with the intellectual movements variously described as post-modernism and and post-structuralism".

21 W G E Watson, Classical Hebrew poetry. A guide to its techniques (JSOT SS 26), Sheffield 21986 .

22 Cf J W Rogerson, Old Testament criticism in the nineteenth century. England and Germany, London 1984; sy mees resente werk in die verband is $W M L$ de Wette and the origins of Biblical criticism, Sheffield 1991.

23 Cf J W Rogerson, Anthropology and the Old Testament, Oxford 1978.

24 Sy benadering word onder andere gereflekteer in een van sy resente publikasies, D J A Clines, What does Eve do to help. And other readerly questions to the Old Testament (JSOT SS 94), Sheffield 1990. 'n Monumentale kommentaar (501pp) op die eerste twintig hoofstukke van die boek Job het ook kort gelede uit sy hand verskyn: Job 1-20 (WBC 17), Dallas 1989. Clines is ook om ander redes ' $n$ invloedryke Ou-Testamentikus. Hy is redakteur van sowel The Dictionary of Classical Hebrew, 'n sintagmaties-analitiese woordeboek, as van die belangrike vakwetenskaplike tydskrif Joumal for the Study of the Old Testament.

25 R E Clements, Old Testament Theology. A fresh approach, London 1978.

26 Vergelyk byvoorbeeld, R E Clements, God's chosen people. A theological interpretation of the book of Deuteronomy, London 1968; Isaiah 1-39 (NCBC), London 1980; Isaiah and the deliverance of Jerusalem: A study in the interpretation of prophecy in the Old Testament (JSOT SS 13), Sheffield 1980. 